\title{
RESEARCHPAPER
}

\section{Socio-economic and demographic descriptions of tribal people subsisting in forest resources of Jharkhand, India}

\author{
M.A. ISLAM'1 ${ }^{1}$ R. RAI ${ }^{2}$, S.M.S. QULI ${ }^{3}$ AND M.S. TRAMBOO ${ }^{1}$ \\ ${ }^{1}$ Faculty of Forestry, Sher-e-Kashmir University of Agricultural Sciences and Technology of Kashmir, Wadura Sopore, \\ BARAMULLA (J\&K) INDIA \\ ${ }^{2}$ Tropical Forest Research Institute, Indian Council of Forestry Research and Education, P.O. R.F.R.C., JABALPUR \\ (M.P.) INDIA \\ ${ }^{3}$ Faculty of Forestry, Birsa Agricultural University, Kanke, RANCHI (JHARKHAND) INDIA \\ Email : ajaz_jsr@yahoo.co.in; ajaztata@gmail.com
}

Article Info :Received : 16.02.2015; Revised : 02.03.2015; Accepted : 16.03 .2015

A field study based on structured interviews and personal observations was carried out to study the socio-economic and demographic characteristics of tribal (Munda, Oraon and Lohara) people subsisting in forest resources of Bundu block in Ranchi district of Jharkhand, India. The primary data were collected from 164 sample households drawn from 9 selected villages employing multi-stage random sampling technique. The results indicated that majority of the respondents were middle aged having low literacy up to primary level, no membership or membership of only one organization with nuclear family systems and large family size. The size of land holding among most of the respondents were either marginal or small, engaged mainly in cultivation having one temporary structured house, one pair of bullocks, medium farm implement possession, 6 to 10 livestock, medium material possession, income from forest resources upto Rs. 8000/ annum and gross annual income upto Rs. 30000/ annum. The surveyed households have higher sex ratio compared to the sex ratio of all India tribal population and over all India population. The unemployment problem is very high among the surveyed population. Hence, the livelihood diversification using existing forest resources should be given topmost priority as important strategy of poverty reduction and socio-economic upliftment of backward tribal people by the policy makers, planners, economists, extension workers and social scientists in the area.

Key words : Socio-economy, Demography, Tribe, Forest, Livelihood, Poverty

How to cite this paper : Islam, M.A., Rai, R., Quli, S.M.S. and Tramboo, M.S. (2015). Socio-economic and demographic descriptions of tribal people subsisting in forest resources of Jharkhand, India. Asian J. Bio. Sci., 10 (1) : 75-82. 